\title{
ANALISIS BERPIKIR KREATIF SISWA DALAM MENYELESAIKAN SOAL PYTHAGORAS MELALUI MODEL JUCAMA
}

\author{
Paulus Koba Kole1, Firda Alfiana Patricia² \\ 1,2 IKIP Budi Utomo Malang
}

firdaalfianapatricia1985@yahoo.com

\begin{abstract}
Abstrak
Pemikiran kreatif dalam pembelajaran di kelas perlu untuk dioptimalkan sehingga siswa lebih memiliki skill dalam menghadapi dan menyelesaikan masalah-masalah yang muncul, khususnya yang berkaitan dengan matematika. Tujuan dari penelitian ini adalah untuk mendeskripsikan kemampuan siswa dalam berpikir kreatif ketika menyelesaikan soal teorema pythagoras dalam pembelajaran dengan model pembelajaran Pengajuan dan Pemecahan Masalah (JUCAMA). Metode penelitian ini adalah penelitian kualitatif. Subjek penelitian ini adalah 6 siswa kelas VIII SMP Negeri 2 Laboya Barat, yang terdiri dari 2 siswa berkemampuan matematika tinggi, 2 siswa berkemampuan matematika sedang, dan 2 siswa berkemampuan matematika rendah. Data yang diambil melalui tes, wawancara dan dokumentasi. Kemudian data dianalisis dan dideskripsikan. Analisis tes berpikir kreatif mengacu pada tiga indikator berpikir kreatif yaitu kefasihan, keluwesan, dan kebaruan. Hasil penelitian diperoleh bahwa siswa yang berkemampuan matematika tinggi dapat memenuhi tiga indikator berpikir kreatif berdasarkan teori siswono karena dapat menunjukkan kefasihan, fleksibilitas, dan kebaharuan. Siswa yang berkemampuan matematika sedang dapat menenuhi dua indikator dan tidak dapat memenuhi kebahauran. Sedangkan, siswa yang berkemampuan matematika rendah tidak memenuhi tiga indikator berdasarkan teori siswono karena tidak fasih, tidak fleksibilitas dan tidak kebaharuan dalam menyelesaikan soal tersebut.
\end{abstract}

Kata kunci: model pembelajaran Jucama, kemampuan berpikir kreatif, teorema Pythagoras

\begin{abstract}
Creative thinking in classroom learning needs to be optimized so that students have more skills in dealing with and solving problems that arise, especially those related to mathematics. The purpose of this study was to describe the ability of students to think creatively when solving pythagorean theorems in learning with the learning model of Submission and Problem Solving (JUCAMA). This research method is qualitative research. The subjects of this study were 6 eighth grade students of SMP Negeri 2 Laboya Barat, which consisted of 2 students with high mathematics abilities, 2 students with moderate mathematics abilities, and 2 students with low math abilities. Data taken through tests, interviews and documentation. Then the data is analyzed and described. Analysis of creative thinking tests refers to three indicators of creative thinking namely fluency, flexibility, and novelty. The results showed that students who have high math skills
\end{abstract}


can fulfill three indicators of creative thinking based on Siswono theory because they can show fluency, flexibility, and renewal. Students with mathematical abilities are able to fulfill two indicators and cannot fulfill happiness. Meanwhile, students with low mathematical abilities do not fulfill three indicators based on Siswono theory because they are not fluent, not flexible and not renewable in solving the problem.

Keywords: JUCAMA learning model, creative thinking ability, Pythagorean theorem

\section{PENDAHULUAN}

Salah satu kebutuhan dasar bagi manusia adalah yang berperan penting untuk keterjaminan kelangsungan hidup manusia dan perkembangannya. Pendidikan sebagai kebutuhan dasar bagi manusia, memegang peranan yang besar dalam perkembangan dan peningkatan kualitas sumber daya manusia. Pendidikan sangat dibutuhkan agar manusia bisa mengembangkan semua potensi yang ada pada dirinya dan bisa memanfaatkan sumber daya alam yang ada, sehingga kelangsungan hidup manusia akan berjalan dengan lancar dan optimal (Syah, 2010: 35).

Sulistiyawati dan Susanah (2013), menyatakan bahwa salah satu bidang studi yang memiliki peranan penting dalam dunia pendidikan adalah matematika. Dengan pengajaran matematika, dapat melatih pola berfikir siswa sehingga memiliki kemampuan kritis dan logis dalam pemecahan masalah. Jadi dengan belajar matematika siswa tidak hanya dapat mengetahui dan memahami yang terkandung dalam matematika tersebut.

Kemampuan berpikir kreatif siswa kurang dilibatkan pada pembelajaran matematika dikelas sehingga masih banyak yang hanya menekankan pada kemampuan pemahaman siswa. Guru kurang memberikan kesempatan kepada siswa agar dapat berkreasi menemukan cara, penyelesaian atau bahkan jawaban yang berbeda dengan yang diajarkan oleh gurunya. Seringkali guru sedikit menghambat siswa dalam menyampaikan pendapat tentang pemahamannya sendiri ketika mempelajari konsep matematika. Akibatnya kemampuan berpikir kreatif siswa tidak akan berkembang. (Siswono, 2008:2).

Zuroidah menyampaikan bahwa penciptaan buah pikiran yang baru dari sekumpulan daya ingat yang terdiri dari ide, konsep, keterangan, pengetahuan, dan pengalaman merupakan kemampuan berpikir kreatif dengan berupa rangkaian tindakan oleh seseorang dengan akal budinya. Ide atau gagasan baru 
Kole, P. K., Patricia, F. A.

Analisis Berpikir Kreatif Siswa dalam Menyelesaikan Soal Pythagoras Melalui Model JUCAMA

akibat dari kegiatan mental seseorang merupakan hasil dari berpikir kreatif. Selain itu, kegiatan mental atau gagasan baru juga merupakan hasil dari berpikir kreatif.

Model pembelajaran yang diterapkan cenderung berorientasi pada pengembangan pemikiran analisis dengan masalah - masalah yang rutin sehingga kemampuan berpikir kreatif jarang ditekankan pada proses pembelajaran matematika. Jarang sekali ditemukan model pembelajaran matematika yang khusus berorientasi pada upaya pengembangan berpikir kreatif matematis. Hafalan dengan menggunakan masalah rutin cenderung diajarkan oleh guru di sekolah sesuai dengan yang disampaikan oleh Siswono (2008:2).

Kurangnya motivasi dalam diri siswa untuk mengembangkan cara yang sudah ada dapat menghambat siswa dalam mengembangkan pemikiran kreatifnya dalam belajar matematika begitupun juga dengan hanya menghafalkan yang sudah diajarkan oleh guru karena pemikiran siswa akan cenderung terpacu untuk hanya sekedar memahami hal-hal yang telah disampaikan kepadanya, bukan mengembangkannya (Zuroidah, 2015). Selain itu, agar siswa lebih terampil dalam menghadapi dan menyelesaikan pemikiran kreatif dalam pembelajaran di kelas sangat penting untuk mengembangkan masalah-masalah yang muncul, khususnya yang berkaitan dengan matematika.

Model pembelajaran matematika yang berorientasi pada pemecahan dan pengajuan matematika sebagai fokus pembelajarannya dan menekankan belajar aktif secara mental dengan tujuan untuk meningkatkan kemampuan berpikir siswa disebut dengan model pembelajaran berbasis pengajuan dan pemecahan masalah (JUCAMA). Model ini didasarkan pada lima teori belajar, yakni (1) Teori Piaget, (2) Teori Vygotski, (3) Teori Bruner, (4) Teori tentang Pemecahan dan Pengajuan Masalah, dan (5) Teori tentang Berpikir Kreatif Siswono (2008:60).

Berdasarkan uraian yang telah dijelaskan sebelumnya maka peneliti merasa bahwa penelitian tentang berpikir kreatif siswa penting sekali untuk dilakukan. Penelitian ini berjudul Analisis Berpikir Kreatif Siswa Dalam Menyelesaikan Soal Teorema Pythagoras Melalui Model Pembelajaran Pengajuan dan Pemecahan Masalah (JUCAMA).

Rumusan masalah dalam penelitian ini adalah untuk bagaimana deskripsi kemampuan berpikir kreatif siswa ketika menyelesaikan soal tentang teorema pythagoras dengan 
didasarkan pada model pengajuan dan pemecahan masalah (JUCAMA). Berdasarkan perumusan masalah penelitian tersebut sehingga penelitian ini bertujuan untuk mendeskripsikan kemampuan berpikir kreatif siswa dalam menyelesaikan soal yang berkaitan dengan teorema pythagoras pada model pembelajaran Pengajuan dan Pemecahan Masalah (JUCAMA).

\section{METODE PENELITIAN}

Pendekatan kualitatif dipilih sebagai penelitian yang digunakan pada studi ini. Penelitian kulitatif menurut Sugiyono (2016:9) merupakan metode penelitian yang berlandaskan pada filsafat postpositivisme yang digunakan untuk meneliti kondisi objek yang bersifat alamiah, sehingga peneliti merupakan intrumen kunci. Teknik pengumpulan data pada penelitian ini dilaksanakan secara triangulasi (gabungan). Analisis data bersifat induktif/kualitatif, dan hasil kualitatif lebih menekankan makna dari pada generalisasi.

Untuk menghasilkan sebuah teori yang dibangun berdasarkan data, yang diperoleh selama penelitian berlangsung merupakan merupakan tujuan dari penelitian kualitatif. Selain itu penelitian kualitatif bertujuan untuk menggambarkan, memahami, dan menjelaskan tentang suatu fenomena yang unik secara mendalam dan lengkap dengan prosedur dan teknik yang khusus sesuai dengan karakteristik penelitian kualitatif (Zuroidah, 2015).

Jenis penelitian yang digunakan oleh peneliti yaitu penelitian deskriptif. Memaparkan atau menggambarkan sesuatu hal, misalkan keadaan, kondisi, situasi, peristiwa, kegiatan dan lain-lain merupakan arti dari istilah "deskriptif" yang berasal dari bahasa inggris yaitu to describe.

Penelitian deskriptif adalah penelitian yang dimaksudkan dengan tujuan untuk menyelidiki suatu keadaan, kondisi atau hal-hal yang sudah disebutkan yang hasilnya dipaparkan dalam bentuk laporan (Arikunto, 2013). Penelitian ini bertujuan untuk membuat deskripsi berpikir kreatif siswa dalam menyelesaikan soal teorema pythagoras yang ditinjau dari tiga komponen yakni; kefasihan, fleksibitas dan kebaruan.

Penelitian ini dilaksanakan di SMP Negeri 2 Laboya Barat yang beralamat di Desa Wetana, Kecamatan Laboya Barat, Kabupaten Sumba Barat, Provinsi Nusa Tenggara Timur. Penelitian ini berjalan selama dua bulan dimulai dari 19 Februari 2018 sampai dengan 19 April 2018. Subjek penelitian ini adalah siswa SMP Negeri 2 Laboya Barat kelas VIII pada tahun ajaran 2018/2019. Pengambilan subjek yang terdiri 
dari 6 orang siswa yaitu 2 siswa berkampuan matematika tinggi, 2 siswa berkemampuan matematika sedang dan 2 siswa berkemmpuan matematika rendah.

\section{Sugiyono}

berpendapat bahwa langkah yang paling strategis dalam penelitian adalah dengan teknik pengumpulan data karena tujuan utama dari penelitian adalah untuk mendapatkan data. Pada umumnya terdapat empat macam teknik pengumpulan data diantaranya observasi, wawancara, dokumentasi, dan gabungan atau triangulasi. Dalam penelitian ini menggunakan tiga teknik pengumpulan data diantaranya wawancara, tes dan dokumentasi.

Rincian instrumen penelitian yang digunakan dalam penelitian ini diantaranya soal tes berpikir kreatif dan pedoman wawancara. Menurut Sugiyono dalam Djamal (2015:138), proses mencari dan menyusun secara sistematis data yang diperoleh melalui wawancara mendalam, catatan lapangan dan bahan-bahan lain, sehingga mudah dipahami dan hasil temuannya dapat disampaikan kepada orang lain merupakan analisis data dalam penelitian kulitatif.

Menurut Zuroidah analisis data adalah suatu upaya yang dilakukan oleh peneliti agar dapat merumuskan hipotesis kerja dengan jalan bekerja dengan data, pengorganisasian dan pengurutan data ke dalam pola, kategori dan uraian dasar serta memutuskan apa yang dapat diceritakan kepada orang lain (Sugiyono, 2016:224) teknik pengumpulan data merupakan langkah yang paling strategis dalam penelitian, karena tujuan utama dari penelitian adalah mendapatkan data. Secara umum terdapat empat macam teknik pengumpulan data, yaitu observasi, wawancara, dokumentasi, dan gabungan/triangulasi. Penelitian ini menggunakan tiga teknik pengumpulan data, yaitu wawancara, tes dan dokumentasi.

Instrumen penelitian yang digunakan yaitu soal tes berpikir kreatif dan pedoman wawancara. Menurut Sugiyono dalam Djamal (2015:138), analisis data dalam penelitian kulitatif merupakan proses mencari dan menyusun secara sistematis data yang diperoleh melalui wawancara mendalam, catatan lapangan dan bahan-bahan lain, sehingga mudah dipahami dan hasil temuannya dapat disampaikan kepada orang lain. Analisis data bertujuan untuk menyempitkan dan membatasi penemuan-penemuan sehingga menjadi suatu data yang teratur, tersusun dan lebih berarti.

Data dianalisis terlebih dahulu sampai ditemukan jawaban dari pertanyaan penelitian, kemudian akan dilanjutkan dengan pengecekan keabsahan data temuan. Pelaksanaan pengecekan keabsahan data pada penelitian ini 
Kole, P. K., Patricia, F. A.

Analisis Berpikir Kreatif Siswa dalam Menyelesaikan Soal Pythagoras Melalui Model JUCAMA

$\begin{aligned} & \text { melalui tiga teknik yaitu } \\ & \text { ketekunan } \\ & \text { triangulasi dan } \\ & \text { sejawat. }\end{aligned}$
pengamatan,
pemeriksaan

\section{HASIL DAN PEMBAHASAN}

Pemilihan subjek penelitian dilakukan pada siswa yang memiliki kemampuan matematika tinggi, sedang dan rendah, yang direkomendasikan oleh guru mata pelajaran di sekolah tersebut, serta dapat mengkomunikasikan idenya dalam menyelesaikan soal.

Pemilihan subjek penelitian dilakukan pada siswa yang memiliki kemampuan matematika tinggi, sedang dan rendah, yang direkomendasikan oleh guru mata pelajaran di sekolah tersebut, serta dapat mengkomunikasikan idenya dalam menyelesaikan soal.

Peneliti melaksanakan pembelajaran dengan memberikan materi teorema pythagoras karena siswa kelas VIII SMP Negeri 2 Laboya Barat karena siswa belum mendapatkan materi tersebut. Peneliti menggunakan model pembelajaran pengajuan dan pemecahan masalah (JUCAMA) yang akan membuka wawasan peserta didik untuk berpikir kreatif. Setelah selesai pembelajaran peneliti memberikan tes berupa Lembar Kerja Siswa(LKS) untuk dikerjakan.

Pengumpulan data berupa tes dilakukan dengan alokasi waktu pelaksanaan tes 60 menit. Tes tersebut diikuti oleh 6 siswa dari kelas VIII (Delapan) yang menjadi subjek dalam penelitian yang terdiri dari dua siswa bekemampuan tinggi, dua siswa berkemampuan sedang dan dua siswa berkemampuan rendah. Hasil dari tes tersebut digunakan untuk menganalisis berpikir kreatif siswa dalam menyelesaikan soal teorema Pythagoras. Setelah dianalisis kemudian dilanjutkan dengan wawancara. Pengumpulan data dengan teknik wawancara ini dilaksanakan di ruang perpustakaan.

Peneliti melakukan pengkodean kepada setiap siswa untuk mempermudah dalam pelaksanaan penelitian dan dalam analisis data serta untuk menjaga privasi siswa. Adapun daftar peserta wawancara adalah Tabel 1. Dokumentasi dilaksanakan pada saat pelaksaan pembelajaran, tes dan wawancara. Dokumen-dokumen ini digunakan sebagai bukti pelaksanaan penelitian untuk melengkapi data penelitian.

Hasil dari wawancara dengan enam siswa tersebut digunakan untuk menganalisis berpikir kreatif siswa dalam menyelesaikan soal yang berkaitan dengan teorema pythagoras. Melalui wawancara peneliti dapat mengetahui cara berpikir kreatif siswa dalam menyelesaikan soal tersebut. 
Tabel 1 Daftar Peserta Wawancara

\begin{tabular}{|c|c|c|c|}
\hline No & Inisial & JK & $\begin{array}{c}\text { Kemampuan } \\
\text { Matematika }\end{array}$ \\
\hline 1 & AB & P & Tinggi \\
\hline 2 & HD & L & Tinggi \\
\hline 3 & AL & P & Sedang \\
\hline 4 & AP & L & Sedang \\
\hline 5 & FA & P & Rendah \\
\hline 6 & MK & L & Rendah \\
\hline
\end{tabular}

Tabel 2 Hasil Analisis Tes Dan Wawancara

\begin{tabular}{|c|c|c|c|c|}
\hline \multirow{2}{*}{ No } & \multirow{2}{*}{ Inisial } & \multicolumn{3}{|c|}{ Komponen Berpikir Kreatif } \\
\cline { 3 - 5 } & & Kefasihan & Fleksibilitas & Kebaruan \\
\hline 1 & AB & $\checkmark$ & $\checkmark$ & $\checkmark$ \\
\hline 2 & HD & $\checkmark$ & $\checkmark$ & $\checkmark$ \\
\hline 3 & AL & $\checkmark$ & $\checkmark$ & - \\
\hline 4 & AD & $\checkmark$ & $\checkmark$ & - \\
\hline 5 & FA & - & - & - \\
\hline 6 & MK & - & - & - \\
\hline
\end{tabular}

Setelah selesai pelaksanaan tes dan wawancara, peneliti menganalisis hasil pekerjaan siswa. Berdasarkan hasil analisis tes, peneliti menemukan beberapa hal yang akan ditanyakan kepada siswa pada saat wawancara. Hasil tes dan wawancara tersebut akan digunakan oleh peneliti untuk menyusun pengkategorian kemampuan berpikir kreatif siswa yang berpedoman pada teori Siswono.

Peneliti menarik kesimpulan bahwa dari 6 siswa yang menjadi subjek dalam penelitian kelas VIII. SMP Negeri 2 Laboya Barat tidak semua mencapai ketiga indikator komponen berpikir kreatif berdasarkan teori Siswono. Berikut hasil analisis tes dan wawancara dari 6 siswa.
Berdasarkan Tabel 2, siswa AB dan HD yang berkemampuan matematika tinggi dapat memenuhi tiga indikator berpikir kreatif berdasarkan teori Siswono karena dapat menunjukkan kefasihan, fleksibilitas, dan kebaharuan. Siswa AL dan AD yang berkemampuan matematikan sedang dapat menenuhi dua indikator dan tidak dapat memenuhi kebahauran. Sedangkan, siswa FA dan MK yang berkemampuan matematika rendah tidak memenuhi tiga indikator berdasarkan teori siswono karena tidak fasih, tidak fleksibilitas dan tidak kebaharuan dalam menyelesaikan soal tersebut.

Dalam penerapan model pembelajaran pengajuan dan pemecahan yang yang digunakan 
untuk mengembangkan berpikir kreatif siswa belum berhasil karena belum semua subjek dalam penelitian dikatakan mampu berpikir keatif.

\section{KESIMPULAN DAN SARAN}

Berdasarkan hasil tes dan wawancara dari enam siswa yang menjadi subjek dalam penelitian ini, dapat disimpulkan bahwa siswa dua yang berkemampuan matematika tinggi dapat memenuhi tiga indikator berpikir kreatif berdasarkan teori Siswono karena dapat menunjukkan kefasihan, fleksibilitas, dan kebaharuan. Dua siswa yang berkemampuan matematika sedang dapat menenuhi dua indikator dan tidak dapat. memenuhi kebahauran. Sedangkan, dua siswa yang berkemampuan matematika rendah tidak memenuhi tiga indikator berdasarkan teori siswono karena tidak dapat memenuhi kefasihan, fleksibilitas dan kebaharuan dalam menyelesaikan soal tersebut.

Dalam penerapan model pembelajaran pengajuan dan pemecahan yang yang digunakan untuk mengembangkan berpikir kreatif siswa dikatakan belum berhasil karena subjek dalam penelitian belum dikatakan semua berpikir keatif. Siswa yang berkemampuan sedang dan rendah belum mampu memenuhi ketiga indikator berpikir keatif.
Berdasarkan penelitian yang telah dilakukan, peneitian ini dapat dijadikan sebagai bahan kajian dan pengembangan penelitian lanjutan sehingga dapat memberikan kontribusi bagi upaya peningkatan kualitas pendidikan. Pada penelitian ini hanya mampu memberikan sedikit gambaran tentang kemampuan berpikir kreatif siswa, sehingga penelitian lanjutan diharapkan dapat memperdalam kajian tentang kemampuan berpikir kreatif dalam menyelesaikan masalah khususnya di bidang matematika.

\section{DAFTAR PUSTAKA}

Arikunto, Suharsimi. 2013. Prosedur Penelitian Suatu Pendekatan Praktik. Jakarta: PT Rineka Cipta.

Djamal, M. 2015. Paradigma Penelitian Kualitatif. Yogyakarta: Celeban Timur Pustaka Pelajar.

Siswono, Tatag Y.E. 2008. Model Pembelajaran Matematika Berbasis Pengajuan dan Pemecahan Masalah Untuk Meningkatkan Kemampuan Berpikir Kreatif. Unesa University Press.

Sugiyono. 2016. Metode Penelitian Pendidikan (Pendekatan Kuantitatif, Kualitatif, dan $R \& D$ ). Bandung: Alfabeta.

Sulistiyawati \& Susanah. 2013. Penerapan Model Pembelajaran Jucama pada Materi Teorema Pythagoras. 
Kole, P. K., Patricia, F. A.

Analisis Berpikir Kreatif Siswa dalam Menyelesaikan Soal Pythagoras Melalui Model JUCAMA

Unesa. Artikel Tidak Diterbitkan.

Syah, Muhibbin. 2010. Psikologi Pendidikan Dengan Metode Terbaru. Bandung: PT Remaja Rosdakarya.

Zuroidah, Eliyatuz. 2015. Analisis Kemampuan Berpikir KreatifSiswa Kelas X Dalam Menyelesaikan Soal Persamaan Kuadrat Di Ma Aswaja Ngunut Tulungagung Tahun Ajaran 2014/2015. Tulungagung. Skripsi. Tidak Diterbitkan. 